\title{
The Inheritance of Yield Components and Beta Carotene Content in Sweet Potato
}

\author{
Heritier Kambale Mbusa ${ }^{1,2}$, Kahiu Ngugi ${ }^{2}$, Florence M. Olubayo ${ }^{2}$, Benjamin Musembi Kivuva ${ }^{3}$, \\ James W. Muthomi ${ }^{2} \&$ Felister M. Nzuve ${ }^{2}$ \\ ${ }^{1}$ Faculty of Agricultural Sciences, Université Catholique du Graben, Democratic Republic of Congo \\ ${ }^{2}$ Department of Plant Science and Crop Protection, Faculty of Agriculture, University of Nairobi, Kenya \\ ${ }^{3}$ Kenya Agricultural and Livestock Research Organization (KALRO), Kenya \\ Correspondence: Heritier Kambale Mbusa, Faculty of Agricultural Sciences, Université Catholique du Graben \\ P.O. Box 29 Butembo, Nord-Kivu, Democratic Republic of Congo. Tel: 254-739-952-535. E-mail: \\ heritiermbaf@gmail.com
}

Received: October 23, 2017

Accepted: November 29, $2017 \quad$ Online Published: January 15, 2018

doi:10.5539/jas.v10n2p71

URL: https://doi.org/10.5539/jas.v10n2p71

\begin{abstract}
Analysis of the gene action exhibited by an agronomic trait in crop plants is useful in the planning of an effective plant breeding program. This study sought to establish the inheritance variance of root yield components and beta carotene content present in sweet potato clones commonly grown in Kenya. Ten contrasting parents were selected based on their beta carotene content, dry matter content and yield potential. They were planted in pots in the green house at KEPHIS-Muguga, Kenya, where they were grafted into Ipomoea setosa to boost their ability to flower. Five parents were further selected based on their ability to flower under local environmental conditions and crossed in a $5 \times 5$ half diallel manner. Five parents and ten $\mathrm{F}_{1}$ clones arising from this hybridization were evaluated at KALRO-Kiboko, Kenya during two rainy seasons. The field trials were laid out in a randomized complete block design of three replications. The data were scored for root yield characteristics, beta carotene and root dry matter content. Griffing Method II, Model 1 diallel was used to estimate the general and specific combining ability. Genetic variability for beta carotene and root dry matter content indicated that the two traits were controlled mostly by both additive and dominant gene actions. Heterosis gene effects were found for beta carotene and root dry matter content which would be useful in the improvement of sweet potato productivity.
\end{abstract}

Keywords: beta carotene content, general combining ability, gene action, heterosis, specific combining ability, sweet potato

\section{Introduction}

Vitamin A deficiency (VAD) is a chronic and widespread public health problem affecting mainly women and children aged under five years in Kenya (Low et al., 1997, 2017). Vitamin A plays an important role in immune system functions and in the survival, growth and development of children, adolescent girls and women of reproductive age (Stathers et al., 2013, 2015). Vitamin A deficiency can be alleviated in several ways including dietary diversification, fortification, supplementation and bio-fortification (Low et al., 2009; WHO, 2009; Harvest Plus, 2012). Among these different ways, bio-fortification which is the genetic enhancement of the edible part of the plant with micronutrient content is the most cost effective and the safest. Bio-fortification can also be achieved through breeding by selection of farmer and consumer preferred traits in genotypes with adequate amount of micronutrient (Low et al., 2001; Harvest Plus, 2012).

Orange fleshed sweet potatoes (OFSP) provide vitamin A rich food which can assist in combating the deficiency amongst poor people in Kenya. Several approaches have been used made to make available orange fleshed sweet potatoes, including introduction of new genotypes and breeding sweet potato for high beta carotene content. The latter can be achieved by making crosses between high beta carotene content genotypes and low or no beta carotene content clones (Stathers et al., 2015). Several mating designs such as the diallel mating designs have been formulated to maximize genetic gains in such crosses. According to Hyaman (1954) and Griffing (1956), the diallel mating design is the most balanced and systematic experimental design to examine continuous 
variation because it generates genetic information related to parental populations and estimates genetic variances in terms of general combining ability (GCA) and specific combining ability (SCA). This study utilized this method to elucidate the inheritance of beta carotene and dry matter content in sweet potato $\mathrm{F}_{1}$ 's progenies.

\section{Materials and Methods}

\subsection{Parental Lines and Crosses}

Parental clones were selected based on their potential beta carotene content, root dry matter and root yield. They were planted in pots in International Potato Center (CIP) green house at KEPHIS-Muguga $\left(1^{\circ} 13^{\prime} \mathrm{S} ; 36^{\circ} 38^{\prime} \mathrm{E}\right.$ and $2096 \mathrm{~m}$ asl) where they were grafted into Ipomoea setosa to boost their flowering ability.

Hand pollinations were carried out in a $5 \times 5$ half diallel mating design between May and November 2016. After emasculations, buds to be used in pollination and as pollen sources were prevented from opening the next morning to avoid all contaminations. The next morning, pollinations were made as soon as anthers begin dehiscing, about $06 \mathrm{~h} 00$ to $09 \mathrm{~h} 00$. The anthers were removed from the protected flowers with tweezers and the pollen applied to the stigma of the desired female parent. Three to seven days after pollination, the crossed females were inspected and those that had been successfully pollinated as evidenced by swollen ovaries were counted and recorded. Table 1 shows the crosses made and their successful rate.

Table 1. Crosses made and their successful rate

\begin{tabular}{llll}
\hline Crosses & Number of crosses made & Number of successful crosses & Rate of success $(\%)$ \\
\hline TJ $\times$ KK & 42 & 30 & 71.43 \\
TJ $\times$ IND & 38 & 20 & 52.63 \\
TJ $\times$ DLV & 30 & 14 & 46.67 \\
TJ $\times$ LD & 53 & 35 & 66.04 \\
KK $\times$ IND & 45 & 31 & 68.89 \\
KK $\times$ DLV & 16 & 9 & 56.25 \\
KK $\times$ LD & 40 & 24 & 60.00 \\
IND $\times$ DLV & 23 & 9 & 39.13 \\
IND $\times$ LD & 50 & 39 & 78.00 \\
DLV $\times$ LD & 49 & 33 & 67.35 \\
\hline Total & 386 & 244 & 63.21 \\
\hline
\end{tabular}

The seeds obtained were germinated in jiffy pots after sand paper scarification and transplanted into nursery pots in the green house. Vine cuttings from each genotype were sown in the field after four months in the seedling nursery for rapid multiplication. Table 2 shows the characteristics of the five sweet potato parental clones.

Table 2. Characteristics of five parental sweet potato clones selected for $5 \times 5$ diallel hybridization

\begin{tabular}{llllll}
\hline ID & Parental name & Origin & BCC $(\mathrm{mg} / 100 \mathrm{~g})$ & DMC $(\%)$ & Yield $\left(\right.$ tha $\left.^{-1}\right)$ \\
\hline KK & Kakamega & Kenya & 3.537 & 27.37 & 19.10 \\
LD & Lourdes & Mozambique & 9.853 & 22.26 & 34.63 \\
TJ & Tio Joe & Mozambique & 10.04 & 21.29 & 33.96 \\
IND & Ininda & Mozambique & 4.945 & 22.52 & 54.79 \\
DL & Delvia & Mozambique & 4.671 & 27.12 & 37.35 \\
\hline
\end{tabular}

Note. Yields based on data from the field trial evaluation at Kabete and KALRO-Kiboko across two seasons.

\subsection{Experimental Design}

Ten families comprising of $180 \mathrm{~F}_{1}$ progenies were raised in a seedling nursery at KEPHIS-Muguga. Thirty cuttings from each family were evaluated alongside their parents (thirty cuttings per parental clone) at KALRO-Kiboko located in Makueni county in Eastern Kenya during two seasons using randomized complete block design (RCBD) laid out in three replications. All clones were planted in a double row on ridges of $1.5 \mathrm{~m}$ long for five plants per genotype per row at spacing of $30 \mathrm{~cm}$ within the row and $90 \mathrm{~cm}$ between rows. 


\subsection{Data Collection}

Fleshed and skin color characteristics and their corresponding amount of beta carotene and vitamin A were recorded after harvest. For beta carotene the color chart was used for selection (Burgos et al., 2009). All the quantitative data were scored on individual plant basis and averaged across the thirteen genotypes for each family. The quantitative traits were recorded as follows: total number of storage roots per plant (NSR) was determined by counting five tagged plants on each plot roots. Fresh root yield (FRY) was measured in kilograms as the combined harvested root on each plot using a balancing scale and the recorded weight per plot unit was extrapolated to tonnes per hectare (t/ha). Fresh biomass weight (FBW) was measured in kilograms as the harvested root together with fresh cut vines per plot and was extrapolated to tonnes per hectare ( $t / h a)$. Harvest index (HI) was estimated as the ratio of the fresh root yield and fresh biomass weight and expressed in percentage. Root dry matter content (RDMC) was determined as the percent of the ratio of root dry weight over fresh root weight. Beta carotene content (BCC) was estimated using the method described by Burgos et al. (2014) in $\mathrm{mg}$ per $100 \mathrm{gm}$ of fresh weight.

\subsection{Data Analysis}

Analysis of variance for number of storage roots, fresh root yield, fresh biomass weight, harvest index, beta carotene and root dry matter content was calculated using GENSTAT $15^{\text {th }}$ edition software. Comparison of means was done using the Fisher's protected least significant differences (LSD) test at 5\% significance level.

Griffing Method II, Model 1 was used to estimate combining ability as performed by SAS software by Sharma (2006) equation:

$$
\mathrm{y}_{\mathrm{ij}}=\mu+\mathrm{g}_{\mathrm{i}}+\mathrm{g}_{\mathrm{j}}+\mathrm{s}_{\mathrm{ij}}
$$

Where, $y_{i j}$ is the mean phenotypic value, $\mu$ is the general mean, $g_{i}$ and $g_{j}$ are GCA effects of $i^{\text {th }}$ and $j^{\text {th }}$ parents respectively and $s_{i j}$ is SCA effects of cross $i \times j$.

GCA and SCA effects for individual lines were calculated using the following formulas of Sharma (2006); Chukwu et al. (2016) and Fasahat et al. (2016), which are:

$$
\begin{gathered}
g_{i}=\frac{1}{(P+2)}\left(x_{i .}+x_{i i}-\frac{2 X}{P}\right) \\
s_{i j}=x_{i j}-\frac{x_{i .}+x_{i i}+x_{. j}+x_{i j}}{P+2}+\frac{2 X .}{(P+1)(P+2)}
\end{gathered}
$$

Where, $g_{i}$ and $s_{i j}$ are general and specific combining ability respectively, $P=$ number of parents, $x_{i .}, x_{i j}$ and $X$. are marginal mean for the $\mathrm{i}^{\text {th }}$ parent, marginal mean for the cross of $\mathrm{i}^{\text {th }}$ and $\mathrm{j}^{\text {th }}$ parents and grand mean.

The relative importance of GCA and SCA were estimated using the general predicted ratio (GPR) for the traits observed (Baker, 1978). A relatively larger GCA/SCA variance ratio demonstrated the importance of additive genetic effects whereas a lower ratio indicated the predominance of dominance gene effects (Christie \& Shathick, 1992). According to Baker (1978), the GCA/SCA ratio is equal to:

$$
\frac{\mathrm{GCA}}{\mathrm{SCA}}=\frac{2 \mathrm{MS}_{\mathrm{GCA}}}{2 \mathrm{MS}_{\mathrm{GCA}}+\mathrm{MS} \mathrm{SCA}}
$$

Where, $\mathrm{MS}_{\mathrm{GCA}}$ is Main Square of general combining ability (GCA) and $\mathrm{MS}_{\mathrm{SCA}}$ is Main Square of specific combining ability (SCA).

Heritability in the broad sense from the diallel mating design was estimated using the general and specific combining ability variances. The following formulas give the estimated broad sense heritability (Harriman \& Nwammadu, 2016).

$$
\mathrm{H}^{2}=\frac{\mathrm{v}_{\mathrm{GCA}}+\mathrm{V}_{\mathrm{SCA}}}{\mathrm{V}_{\mathrm{GCA}}+\mathrm{V}_{\mathrm{SCA}}+\mathrm{V}_{\mathrm{E} / \mathrm{r}}}
$$

Where, $\mathrm{V}_{\mathrm{P}}$ is the phenotypic variance, $\mathrm{V}_{\mathrm{GCA}}$ and $\mathrm{V}_{\mathrm{SCA}}$ are general and specific combining ability variance respectively and $\mathrm{H}^{2}$ is broad sense heritability.

Mid parent (MPH) and better parent heterosis (BPH) were estimated for fresh root yield (FRY), beta carotene content (BCC) and root dry matter content (DMC) using Falconer and Mackay (1996) formulae:

$$
\begin{aligned}
& \mathrm{MPH}=\frac{\mathrm{F}_{1}-\mathrm{MP}}{\mathrm{MP}} \times 100 \\
& \mathrm{BPH}=\frac{\mathrm{F}_{1}-\mathrm{BP}}{\mathrm{BP}} \times 100
\end{aligned}
$$

Where, $F_{1}$ is mean of $F_{1}$ hybrids, MP is mean of the two parents involved in the cross and BP is the mean of the better parent in the cross. 


\section{Results}

\subsection{Skin and Flesh Color of Parental Clones and Their Crosses}

More than $30 \%$ of the clones studied were red in color. The following progeny genotypes, TJ $\times$ IND, KK $\times$ IND, IND $\times$ LD and parental clone Tio-Joe had brown skin color. Parental clone Ininda and progenies, TJ $\times$ LD, IND $\times$ DLV and DLV $\times$ LD were pink in skin color whereas parental clones Delvia and Lourdes were purple and cream. The color chart revealed that progeny clones from the crosses $\mathrm{TJ} \times \mathrm{LD}$ and $\mathrm{DLV} \times \mathrm{LD}$ were deep orange in flesh color. Genotypes from TJ $\times$ KK, KK $\times$ DLV and IND $\times$ LD had intermediate orange flesh color while progenies TJ $\times$ IND, KK $\times$ LD and IND $\times$ DLV had pale yellow flesh color. Progeny genotypes, TJ $\times$ DLV and KK $\times$ IND were cream and pale yellow orange in flesh color. Most of the parental clones had intermediate orange flesh color except for clones, Tio-Joe and Ininda, which had deep orange and orange flesh color (Table $3)$.

Table 3. Skin and flesh color of sweet potato parental clones and their crosses

\begin{tabular}{lllll}
\hline Genotypes & Skin color & Flesh color & BCC $(\mathrm{mg} / 100 \mathrm{~g})$ & Vit. A $(\mu \mathrm{g}$ RE $/ 100 \mathrm{~g})$ \\
\hline $\mathrm{TJ} \times \mathrm{KK}$ & Red & 28-D: Intermediate orange & 4.92 & 410 \\
$\mathrm{TJ} \times \mathrm{IND}$ & Brown & 9-D: Pale yellow & 0.12 & 10 \\
$\mathrm{TJ} \times \mathrm{DLV}$ & Red & 11-D: Cream & 0.03 & 2.5 \\
$\mathrm{TJ} \times \mathrm{LD}$ & Pink & 28-A: Deep orange & 11.03 & 919.2 \\
$\mathrm{KK} \times \mathrm{IND}$ & Brown & 16-D: Pale yellow orange & 0.15 & 12.5 \\
$\mathrm{KK} \times \mathrm{DLV}$ & Red & 29-A: Intermediate orange & 3.76 & 313.3 \\
$\mathrm{KK} \times \mathrm{LD}$ & Red & 9-D: Pale yellow & 0.12 & 10 \\
$\mathrm{IND} \times \mathrm{DLV}$ & Pink & 9-D: Pale yellow & 0.12 & 10 \\
$\mathrm{IND} \times \mathrm{LD}$ & Brown & 29-A: Intermediate orange & 3.03 & 252.5 \\
$\mathrm{DLV} \times \mathrm{LD}$ & Pink & 30-D: Deep orange & 12.39 & 1032.5 \\
Tio-Joe & Brown & 30-D: Deep orange & 10.5 & 875 \\
Kakamega & Red & 28-C: Intermediate orange & 3.96 & 330 \\
Ininda & Pink & 25-A: Orange & 6.12 & 510 \\
Delvia & Purple & 28-C: Intermediate orange & 3.96 & 330 \\
Lourdes & Cream & 28-C: Intermediate orange & 5.49 & 457.5 \\
\hline
\end{tabular}

Note. 1) $\mathrm{BCC}=$ beta carotene content; 2) Vit. $\mathrm{A}=$ vitamin $\mathrm{A}$; and, 3) $\mathrm{RE}=$ retinol equivalents.

\subsection{Field Trail}

There were highly significant differences among the genotypes at $\mathrm{p}<0.001$ for all the traits studied except for number of storage root (NSR) and fresh root yield (FRY) indicating that there were genetic variations among genotypes tested for fresh root yield and beta carotene content. Seasons showed highly significant differences except for beta carotene content and dry matter content indicating that these two later traits are less likely to be influenced by environmental effects. Genotypes $\times$ season interaction variances were not significantly different for all the traits under consideration $(\mathrm{p}>0.05)$ but the genotypes differed significantly amongst each other, meaning that selection for those traits could be carried out at an early stage of the $F_{1}$ progenies. The GCA and SCA mean squares for all the traits studied were not significantly different for all traits $(p>0.05)$ except for beta carotene and dry matter content at $p<0.001$. The GCA $\times$ Seasons interaction effect was significant for all the traits except for fresh biomass weight. SCA $\times$ season interaction, showed significant differences for all the traits except for number of storage roots and harvest index. The Becker ratios were more than 0.50 for all the traits indicating that the expression of those traits was mainly affected by additive gene action (Table 4). 
Table 4. Mean squares and Baker ratio for plant growth parameters yield and yield parameters and nutrient contents for the $\mathrm{F}_{1}$ 's progenies and their parents

\begin{tabular}{llllllll}
\hline Source of variation & DF & NSR & Y & WB & HI & BCC & DMC \\
\hline Blocks & 2 & 4.41 & 27.14 & 30.6 & 49.74 & 0.01 & 0.53 \\
Genotypes & 14 & $1.47^{*}$ & $157.55^{*}$ & $421.44^{*}$ & $276.96^{* * *}$ & $104.75^{* * *}$ & $82.04^{* * *}$ \\
Seasons & 1 & $118.45^{* * *}$ & $2320.95^{* * *}$ & $989.63^{*}$ & $2758.26^{* * *}$ & $0.02^{\mathrm{ns}}$ & $0.29^{\mathrm{ns}}$ \\
Genotypes $\times$ Seasons & 14 & $0.62^{\mathrm{ns}}$ & $23.72^{\mathrm{ns}}$ & $37.50^{\mathrm{ns}}$ & $17.09^{\mathrm{ns}}$ & $0.01^{\mathrm{ns}}$ & $0.22^{\mathrm{ns}}$ \\
GCA & 4 & $0.48^{\mathrm{ns}}$ & $38.33^{\mathrm{ns}}$ & $58.08^{\mathrm{ns}}$ & $68.30^{\mathrm{ns}}$ & $26.95^{* * *}$ & $12.67^{* * *}$ \\
SCA & 10 & $0.33^{\mathrm{ns}}$ & $26.96^{\mathrm{ns}}$ & $82.89^{\mathrm{ns}}$ & $41.23^{\mathrm{ns}}$ & $13.36^{* * *}$ & $14.21^{* * *}$ \\
GCA $\times$ Seasons & 4 & $0.59^{* *}$ & $39.13^{*}$ & $51.09^{\mathrm{ns}}$ & $100.03^{* * *}$ & $28.38^{* * *}$ & $12.11^{* * *}$ \\
SCA $\times$ Seasons & 10 & $0.18^{\mathrm{ns}}$ & $22.76^{*}$ & $78.63^{*}$ & $24.83^{\mathrm{ns}}$ & $13.09^{* * *}$ & $14.25^{* * *}$ \\
Error & 58 & 0.75 & 65.89 & 180.07 & 78.41 & 0.01 & 0.27 \\
Backer ratio & & 0.74 & 0.74 & 0.58 & 0.77 & 0.80 & 0.64 \\
\hline
\end{tabular}

Note. ${ }^{\text {ns }}, *, * *$ and $* * *=$ no, significant, high significant and very high significant difference respectively; d.f. $=$ degree of freedom; GCA and SCA $=$ General and Specific combining ability respectively; NSR $=$ Number of storage root; $\mathrm{Y}=$ Fresh root yield; $\mathrm{WB}=$ fresh biomass weight; $\mathrm{HI}=$ Harvest index, $\mathrm{BCC}=$ Beta carotene content and $\mathrm{DMC}=$ Dry matter content.

\subsection{Phenotype Performance of Parental Clones and Their Crosses}

Clones, Tio-Joe, Lourdes and Kakamega yielded the highest number of storage roots of 4.5, 4.0 and 3.8, respectively. Progenies from crosses, TJ $\times$ LD, TJ $\times$ DLV and $\mathrm{KK} \times \mathrm{DLV}$ provided the highest number of storage roots of 4.0, 3.6 and 3.4, respectively, across the two seasons. Clone, Tio-Joe had the highest fresh root yield of $33.34 \mathrm{t} / \mathrm{ha}$ followed by Ininda and Delvia with $27.83 \mathrm{t} / \mathrm{ha}$ and $27.49 \mathrm{t} / \mathrm{ha}$ respectively. The progenies of $\mathrm{IND} \times \mathrm{LD}, \mathrm{TJ} \times \mathrm{LD}$ and TJ $\times \mathrm{KK}$ provided the highest mean fresh root yield of $40.19 \mathrm{t} / \mathrm{ha}, 37.70 \mathrm{t} / \mathrm{ha}$ and 34.23 $\mathrm{t} / \mathrm{ha}$ respectively but genotypes from the cross, IND $\times \operatorname{DLV}(23.73 \mathrm{t} / \mathrm{ha})$ had the lowest fresh root yield. Clone, Tio-Joe had the highest fresh biomass weight of $49.90 \mathrm{t} / \mathrm{ha}$ followed by clones, Lourdes and Delvia which provided a fresh biomass weight mean of $47.38 \mathrm{t} / \mathrm{ha}$ and $45.84 \mathrm{t} / \mathrm{ha}$, across seasons. The highest fresh biomass weight was recorded for the crosses IND $\times$ LD, KK $\times$ IND and DLV $\times$ LD with means of $74.97 \mathrm{t} / \mathrm{ha}, 60.95 \mathrm{t} / \mathrm{ha}$ and $54.89 \mathrm{t} / \mathrm{ha}$, respectively (Table 5). Clones, Tio-Joe and Ininda had higher mean harvest index of $69.87 \%$ and $62.70 \%$, respectively. The $\mathrm{F}_{1}$ progenies of $\mathrm{TJ} \times \mathrm{KK}, \mathrm{TJ} \times \mathrm{DLV}$ and $\mathrm{TJ} \times \mathrm{IND}$ had the highest harvest index of $75.17 \%, 65.51 \%$ and $62.52 \%$, respectively.

Clone, Tio-Joe had the highest beta carotene content of $10.210 \mathrm{mg} / 100 \mathrm{~g}$ followed by clones, Ininda and Lourdes which provided $5.904 \mathrm{mg} / 100 \mathrm{~g}$ and $5.394 \mathrm{mg} / 100 \mathrm{~g}$ respectively. Clone, Kakamega had the lowest beta carotene concentration of $3.163 \mathrm{mg} / 100 \mathrm{~g}$. Progenies of DLV $\times \mathrm{LD}$, TJ $\times \mathrm{LD}$ and TJ $\times \mathrm{IND}$ yielded the highest beta carotene contents of $12.049 \mathrm{mg} / 100 \mathrm{~g}, 11.030 \mathrm{mg} / 100 \mathrm{~g}$ and $7.174 \mathrm{mg} / 100 \mathrm{~g}$ respectively but crosses from $\mathrm{IND} \times \mathrm{LD}, \mathrm{KK} \times \mathrm{IND}$ and KK $\times$ DLV had the lowest beta carotene contents of $0.117 \mathrm{mg} / 100 \mathrm{~g}, 0.048 \mathrm{mg} / 100 \mathrm{~g}$ and $0.030 \mathrm{mg} / 100 \mathrm{~g}$ respectively (Table 5). Clone, Delvia yielded the highest dry matter content of $29.34 \%$ whereas clone, Lourdes provided the lowest dry matter content of 21.69. The progenies of IND $\times$ LD and IND $\times$ DLV had the highest dry matter content of 29.38 and $28.83 \%$; however the cross of DLV $\times$ LD yielded the lowest dry matter content of $15.53 \%$ (Table 5). 
Table 5. Performance of five sweet potato parental clones and their progenies for yield and yield parameters and nutrient contents

\begin{tabular}{lllllll}
\hline Genotypes & NSR $\left(\mathrm{n}^{\circ}\right)$ & $\mathrm{Y}(\mathrm{t} / \mathrm{ha})$ & WB $(\mathrm{t} / \mathrm{ha})$ & HI $(\%)$ & BCC $(\mathrm{mg} / 100 \mathrm{~g})$ & $\mathrm{DMC}(\%)$ \\
\hline $\mathrm{TJ} \times \mathrm{KK}$ & 3.4 & 34.23 & 45.84 & 75.17 & 2.363 & 20.68 \\
$\mathrm{TJ} \times \mathrm{IND}$ & 3.0 & 32.86 & 52.87 & 62.52 & 7.174 & 26.00 \\
$\mathrm{TJ} \times \mathrm{DLV}$ & 3.6 & 29.64 & 45.34 & 65.51 & 4.934 & 26.64 \\
$\mathrm{TJ} \times \mathrm{LD}$ & 4.0 & 37.70 & 50.68 & 58.01 & 11.030 & 21.74 \\
$\mathrm{KK} \times \mathrm{IND}$ & 3.2 & 30.37 & 60.95 & 61.30 & 0.048 & 25.82 \\
$\mathrm{KK} \times \mathrm{DLV}$ & 3.4 & 29.69 & 50.16 & 58.91 & 0.030 & 26.34 \\
$\mathrm{KK} \times \mathrm{LD}$ & 2.6 & 26.73 & 51.59 & 52.18 & 0.332 & 26.02 \\
$\mathrm{IND} \times \mathrm{DLV}$ & 2.9 & 23.73 & 42.61 & 56.37 & 0.129 & 28.86 \\
$\mathrm{IND} \times$ LD & 3.2 & 40.19 & 74.97 & 53.13 & 0.117 & 29.38 \\
$\mathrm{DLV} \times \mathrm{LD}$ & 3.0 & 30.37 & 54.89 & 55.27 & 12.049 & 15.53 \\
Tio-Joe & 4.5 & 33.34 & 49.90 & 69.87 & 10.210 & 25.20 \\
Kakamega & 3.8 & 20.84 & 42.50 & 49.76 & 3.163 & 26.08 \\
Ininda & 3.6 & 27.83 & 44.00 & 62.70 & 5.904 & 24.76 \\
Delvia & 3.3 & 27.49 & 45.84 & 59.75 & 4.011 & 29.34 \\
Lourdes & 4.0 & 25.33 & 47.38 & 55.54 & 5.394 & 21.69 \\
\hline MEAN & 3.4 & 29.98 & 50.63 & 59.73 & 4.459 & 24.94 \\
LSD & 1.0 & 9.38 & 15.51 & 10.23 & 0.121 & 0.60 \\
C.V. $(\%)$ & 25.29 & 27.07 & 26.50 & 14.82 & 2.350 & 2.07 \\
\hline
\end{tabular}

Note. L.S.D. $=$ Least significant difference; C.V. $=$ Coefficient of variation; NMR $=$ number of marketable roots per plant; NUR = number of unmarketable roots per plant; NSR $=$ number of storage roots per plant, FRY $=$ fresh root yield (t/ha) and $\mathrm{WB}=$ fresh biomass weight ( $\mathrm{t} / \mathrm{ha}), \mathrm{BCC}=$ beta carotene content and $\mathrm{DMC}=$ dry matter content.

\subsection{General Combining Ability Effects}

The GCA effects of most parental clones were positive and significant at $\mathrm{p}<0.05$. Clones, Tio-Joe and Lourdes had positive and negative significant GCA effect for harvest index (HI) respectively (Table 6).

GCA effects of Tio-Joe and Lourdes were positive and highly significant $(\mathrm{p}<0.001)$ for beta carotene content whereas these effects were negative for clones, Kakamega, Ininda and Delvia. Positive and highly significant GCA effects for root dry matter were observed for genotypes, Kakamega, Ininda and Delvia for dry matter content (Table 6).

Table 6. Estimation of GCA effects for number of storage root, fresh root yield, biomass weight, harvest index, beta carotene and dry matter content of five sweet potato parents

\begin{tabular}{lllllll}
\hline Parents & NSR $\left(\mathrm{n}^{\circ}\right)$ & FRY $(\mathrm{t} / \mathrm{ha})$ & $\mathrm{WB}(\mathrm{t} / \mathrm{ha})$ & $\mathrm{HI}(\%)$ & $\mathrm{BCC}(\mathrm{mg} / 100 \mathrm{~g})$ & DMC $(\%)$ \\
\hline Tio-Joe & $0.90^{* *}$ & $1.61^{\mathrm{ns}}$ & $-1.32^{\mathrm{ns}}$ & $6.08^{*}$ & $2.74^{* * *}$ & $-0.74^{* * *}$ \\
Kakamega & $0.52^{*}$ & $-1.41^{\mathrm{ns}}$ & $-1.46^{\mathrm{ns}}$ & $-1.83^{\mathrm{ns}}$ & $-2.53^{* * *}$ & $0.63^{* *}$ \\
Ininda & $0.42^{*}$ & $1.47^{\mathrm{ns}}$ & $2.23^{\mathrm{ns}}$ & $0.05^{\mathrm{ns}}$ & $-1.07 * * *$ & $1.43^{* * *}$ \\
Delvia & $0.40^{*}$ & $-1.43^{\mathrm{ns}}$ & $-2.75^{\mathrm{ns}}$ & $-0.41^{\mathrm{ns}}$ & $-0.35^{* * *}$ & $0.92^{* * *}$ \\
Lourdes & $0.58^{*}$ & $-0.31^{\mathrm{ns}}$ & $3.31^{\mathrm{ns}}$ & $-4.11^{*}$ & $1.08^{* * *}$ & $-1.94^{* * *}$ \\
\hline
\end{tabular}

Note. ${ }^{\text {ns }}, *, * *$ and $* * *=$ no, significant, high significant and very high significant difference respectively; NSR $=$ Number of storage root; FRY $=$ Fresh root yield; WB $=$ fresh biomass weight; HI = Harvest index, $\mathrm{BCC}=$ Beta carotene content and DMC $=$ Dry matter content.

\subsection{Specific Combining Ability Effects}

Only progenies from the cross IND $\times$ LD had significant and high positive SCA effects for fresh root yield, vine weight and biomass weight respectively (Table 7). Progenies from TJ $\times$ KK cross had also significant and high positive SCA effect for harvest index. Highly significant SCA effects were observed for beta carotene and dry matter content for all progenies. The highest positive SCA effects were found in progenies from DLV $\times$ LD and 
IND $\times$ LD crosses which had $6.87 \mathrm{mg} / 100 \mathrm{gm}$ and $8.43 \mathrm{mg} / 100 \mathrm{gm}$ for beta carotene and dry matter content respectively (Table 7).

Table 7. Estimation of SCA effects for number of storage root, fresh root yield, biomass weight, harvest index, beta carotene and dry matter content of ten sweet potato crosses

\begin{tabular}{lllllll}
\hline Crosses & NSR $\left(\mathrm{n}^{\circ}\right)$ & FRY $(\mathrm{t} / \mathrm{ha})$ & WB $(\mathrm{t} / \mathrm{ha})$ & $\mathrm{HI}(\%)$ & BCC $(\mathrm{mg} / 100 \mathrm{~g})$ & DMC $(\%)$ \\
\hline $\mathrm{TJ} \times \mathrm{KK}$ & $-0.30^{\mathrm{ns}}$ & $4.03^{\mathrm{ns}}$ & $-2.00^{\mathrm{ns}}$ & $11.19^{*}$ & $-2.31^{* * *}$ & $-4.15^{* * *}$ \\
$\mathrm{TJ} \times \mathrm{IND}$ & $-0.69^{\mathrm{ns}}$ & $-0.21^{\mathrm{ns}}$ & $1.33^{\mathrm{ns}}$ & $-3.34^{\mathrm{ns}}$ & $1.05^{* * *}$ & $0.39^{* * *}$ \\
$\mathrm{TJ} \times \mathrm{DLV}$ & $-0.05^{\mathrm{ns}}$ & $-0.55^{\mathrm{ns}}$ & $-1.22^{\mathrm{ns}}$ & $0.11^{\mathrm{ns}}$ & $-1.92^{* * *}$ & $1.52^{* * *}$ \\
$\mathrm{TJ} \times \mathrm{LD}$ & $0.18^{\mathrm{ns}}$ & $-1.52^{\mathrm{ns}}$ & $-1.93^{\mathrm{ns}}$ & $-1.13^{\mathrm{ns}}$ & $2.76^{* * *}$ & $-0.53^{* * *}$ \\
$\mathrm{KK} \times \mathrm{IND}$ & $-0.06^{\mathrm{ns}}$ & $7.65^{*}$ & $9.41^{\mathrm{ns}}$ & $3.35^{\mathrm{ns}}$ & $-0.82^{* * *}$ & $-1.18^{* * *}$ \\
$\mathrm{KK} \times \mathrm{DLV}$ & $0.14^{\mathrm{ns}}$ & $2.54^{\mathrm{ns}}$ & $3.74^{\mathrm{ns}}$ & $1.42^{\mathrm{ns}}$ & $-1.57^{* * *}$ & $0.99^{* * *}$ \\
$\mathrm{KK} \times \mathrm{LD}$ & $-0.76^{\mathrm{ns}}$ & $-1.56^{\mathrm{ns}}$ & $-0.88^{\mathrm{ns}}$ & $0.96^{\mathrm{ns}}$ & $-2.69^{* * *}$ & $2.40^{* * *}$ \\
$\mathrm{IND} \times \mathrm{DLV}$ & $-0.17^{\mathrm{ns}}$ & $-6.31^{\mathrm{ns}}$ & $-7.50^{\mathrm{ns}}$ & $-3.00^{\mathrm{ns}}$ & $-2.92^{* * *}$ & $1.58^{* * *}$ \\
$\mathrm{IND} \times \mathrm{LD}$ & $-0.08^{\mathrm{ns}}$ & $9.03^{*}$ & $18.81^{*}$ & $0.02^{\mathrm{ns}}$ & $-4.36^{* * *}$ & $4.96^{* * *}$ \\
$\mathrm{DLV} \times \mathrm{LD}$ & $-0.30^{\mathrm{ns}}$ & $2.12^{\mathrm{ns}}$ & $3.71^{\mathrm{ns}}$ & $2.62^{\mathrm{ns}}$ & $6.87^{* * *}$ & $0.04^{\mathrm{ns}}$ \\
\hline
\end{tabular}

Note. ${ }^{\text {ns }}, *, * *$ and $* * *=$ no, significant, high significant and very high significant difference respectively; d.f. $=$ degree of freedom; GCA and SCA $=$ General and Specific combining ability respectively; NSR $=$ Number of storage root; FRY $=$ Fresh root yield; $\mathrm{WB}=$ fresh biomass weight; $\mathrm{HI}=$ Harvest index, $\mathrm{BCC}=\mathrm{Beta}$ carotene content and $\mathrm{DMC}=$ Dry matter content.

\subsection{Heterosis Effects}

Heterosis was estimated for the ten crosses made. Most of mid and better-parent heterosis values were positive for fresh root yield but were negative for the other traits (Table 8). The highest mid and better parent heterosis values were observed in $\mathrm{F}_{1}$ progenies of $\mathrm{TJ} \times \mathrm{KK}(64.25$ and $2.67 \%)$, IND $\times \mathrm{LD}(58.67$ and $44.41 \%)$ and $\mathrm{TJ} \times$ LD (48.84 and 13.08\%) for fresh root yield (Table 8). $\mathrm{F}_{1}$ progenies from DLV $\times$ LD and TJ $\times$ LD crosses provided the highest beta carotene content mid-parent and better-parent heterosis of $123.38 \%$ and $123.39 \%$, and $104.49 \%$ and $8.03 \%$, respectively but were lowest from KK $\times$ DLV cross. The highest dry matter content mid-parent and better-parent heterosis were observed in progenies from the cross, IND $\times$ LD (35.45 and 18.66\%) (Table 8).

Table 8. Estimates of percent mid-parent (MPH) and better-parent heterosis (BPH) for fresh root yield, beta carotene content and dry matter content of $\mathrm{F}_{1}$ families

\begin{tabular}{|c|c|c|c|c|c|c|}
\hline \multirow{2}{*}{$\begin{array}{l}\text { Parameters } \\
\text { Crosses }\end{array}$} & \multicolumn{2}{|c|}{ FRY (t/ha) } & \multicolumn{2}{|c|}{$\mathrm{BCC}(\mathrm{mg} / 100 \mathrm{~g})$} & \multicolumn{2}{|c|}{ DMC (\%) } \\
\hline & $\mathrm{MPH}$ & $\mathrm{BPH}$ & $\mathrm{MPH}$ & $\mathrm{BPH}$ & $\mathrm{MPH}$ & $\mathrm{BPH}$ \\
\hline $\mathrm{TJ} \times \mathrm{KK}$ & 64.25 & 2.67 & -25.29 & -76.86 & -20.71 & -20.71 \\
\hline $\mathrm{TJ} \times \mathrm{IND}$ & 18.07 & -1.44 & 21.51 & -29.74 & 5.01 & 3.17 \\
\hline $\mathrm{TJ} \times \mathrm{DLV}$ & 7.82 & -11.10 & 23.01 & -51.67 & -9.20 & -9.20 \\
\hline $\mathrm{TJ} \times \mathrm{LD}$ & 48.84 & 13.08 & 104.49 & 8.03 & 0.23 & -13.73 \\
\hline $\mathrm{KK} \times \mathrm{IND}$ & 9.13 & 9.13 & -99.19 & -99.19 & 4.28 & -1.00 \\
\hline $\mathrm{KK} \times \mathrm{DLV}$ & 8.00 & 8.00 & -99.25 & -99.25 & -10.22 & -10.22 \\
\hline $\mathrm{KK} \times \mathrm{LD}$ & 5.53 & 5.53 & -93.85 & -93.85 & 19.96 & -0.23 \\
\hline $\mathrm{IND} \times \mathrm{DLV}$ & -13.68 & -14.73 & -96.78 & -97.82 & -1.64 & -1.64 \\
\hline $\mathrm{IND} \times \mathrm{LD}$ & 58.67 & 44.41 & -97.83 & -98.02 & 35.45 & 18.66 \\
\hline $\mathrm{DLV} \times \mathrm{LD}$ & 19.90 & 10.48 & 123.38 & 123.39 & -28.40 & -47.07 \\
\hline
\end{tabular}

Note. FRY $=$ Fresh root yield $; \mathrm{BCC}=$ Beta carotene content and $\mathrm{DMC}=$ Dry matter content.

\subsection{Heritability}

Beta carotene and dry matter contents exhibited high broad sense heritability values of 99.96 and $98.66 \%$ respectively while harvest index (47.46\%), number of marketable roots $(41.86 \%)$, fresh root yield $(39.90 \%)$ and biomass weight (37.88\%) had the broad sense heritability less than 50\% (Table 9). 
Table 9. Estimated broad sense heritability for number of storage root, fresh root yield, biomass weight, harvest index, beta carotene and dry matter content

\begin{tabular}{lllllll}
\hline Genetic variance & NSR & FRY & WB & HI & BCC & DMC \\
\hline GCA & 1.92 & 153.32 & 232.32 & 273.2 & 107.8 & 50.68 \\
SCA & 3.3 & 269.6 & 828.90 & 412.3 & 133.6 & 142.1 \\
Error & 7.25 & 636.94 & 1740.68 & 757.96 & 0.1 & 2.61 \\
\hline $\mathrm{H}^{2}$ & 41.86 & 39.9 & 37.88 & 47.49 & 99.96 & 98.66 \\
\hline
\end{tabular}

Note. GCA and SCA = General and Specific combining ability respectively; NSR = Number of storage root; $\mathrm{FRY}=$ Fresh root yield; $\mathrm{WB}=$ fresh biomass weight; $\mathrm{HI}=$ Harvest index, $\mathrm{BCC}=$ Beta carotene content and $\mathrm{DMC}=$ Dry matter content.

\subsection{Phenotypic Correlation between Traits Studied}

Table 10 presents Pearson correlation coefficients between all the traits. There was a positive and highly significant correlation between fresh root yield and biomass weight $(\mathrm{r}=0.810)$ but dry matter content and beta carotene content were negatively significantly correlated $(\mathrm{r}=-0.622)$. Beta carotene content from laboratory analysis (BCC) and from color chart (CC) were positive and highly correlated with vitamin A content at $\mathrm{r}=$ 0.788 and $\mathrm{r}=1.000$ respectively.

Table 10. Correlation between traits under consideration

\begin{tabular}{|c|c|c|c|c|c|c|c|}
\hline Traits & NSR & FRY & WB & $\mathrm{HI}$ & $\mathrm{BCC}$ & $\mathrm{CC}$ & Vit. A \\
\hline $\mathrm{Y}$ & $0.482 * * *$ & & & & & & \\
\hline WB & $0.154^{\mathrm{ns}}$ & $0.810 * * *$ & & & & & \\
\hline HI & $0.535 * * *$ & $0.426^{* * *}$ & $-0.162^{\mathrm{ns}}$ & & & & \\
\hline $\mathrm{BCC}$ & $0.151^{\mathrm{ns}}$ & $-0.016^{\mathrm{ns}}$ & $-0.086^{\mathrm{ns}}$ & $0.110^{\mathrm{ns}}$ & & & \\
\hline $\mathrm{CC}$ & $0.176^{\mathrm{ns}}$ & $0.007^{\mathrm{ns}}$ & $-0.018^{\mathrm{ns}}$ & $0.059^{\mathrm{ns}}$ & $0.788 * * *$ & & \\
\hline Vit. A & $0.176^{\mathrm{ns}}$ & $0.007^{\mathrm{ns}}$ & $-0.018^{\mathrm{ns}}$ & $0.059^{\mathrm{ns}}$ & $0.788 * * *$ & $1.000 * * *$ & \\
\hline DMC & $-0.024^{\mathrm{ns}}$ & $0.032^{\mathrm{ns}}$ & $0.085^{\mathrm{ns}}$ & $-0.084^{\mathrm{ns}}$ & $-0.622 * * *$ & $-0.676 * * *$ & $-0.676 * * *$ \\
\hline
\end{tabular}

Note. ${ }^{\text {ns }}, *, * *$ and $* * *=$ no, significant, high and very high significant correlation respectively; NSR $=$ Number of storage roots $\mathrm{FRY}=$ fresh root yield; $\mathrm{WB}=$ biomass weight; $\mathrm{HI}=$ Harvest index, $\mathrm{BCC}=$ Beta carotene content, $\mathrm{CC}=$ Color chart beta carotene content, Vit. $\mathrm{A}=$ vitamin $\mathrm{A}$ and $\mathrm{DMC}=$ Dry matter content.

\section{Discussion}

\subsection{Field Trail}

The results in this study revealed that there were highly significant differences among the genotypes for fresh root yield and beta carotene content indicating that there were genetic variations among genotypes tested .The results also showed that there were significant differences between seasons for number of storage roots, fresh root yield, biomass weight and harvest index. This might imply that the genotypes were not stable across the two seasons probably due to different irrigation levels applied and other environmental conditions. On the contrary, the genotypes showed no significant differences for beta carotene and dry matter content between the two seasons. This may be attributed more to higher genetic variance and less $g \times$ e effects for these traits (Woolfe, 1992). This observation is strengthened by the fact that the GCA and SCA for beta carotene and dry matter contents also were highly significant but these effects were not significant for all the other root yield and yield components (Table 4). This indicated the both additive and dominance gene actions were important in the expression of beta carotene and dry matter content characteristics but less so for all the other traits. These results found in are in agreement with those of Chiona (2009) and Balcha (2015) who also observed significant differences in GCA and SCA for beta carotene and dry matter.

The high ratio of GCA and SCA (Baker ratios) of 0.60 suggest that additive gene action played a dominant role in the expression of the traits under investigation. This implies that the GCA estimates are more reliable and could be used in the prediction of progeny performance of the target traits.

\subsection{General and Specific Combining Ability Effects}

The GCA and SCA effects were not significant for all the yield and yield parameters (Tables 6 and 7) which implies that these traits did not show significant additive and dominance genetic variances. This result is in 
contrast with that of Chiona (2009) and Balcha (2015) who found significant GCA and SCA effects for the yield and yield parameters in Malawi and Ethiopia. The reason for this discrepancy can be explained by the fact that the parental lines used were selected solely based on beta carotene and dry matter content but not on other agronomic characteristics. Furthermore, both parental clones and the $F_{1}$ progenies in this study were harvested before the physiological maturity which could have had an effect on yield and yield parameters.

The general combining ability effects for beta carotene and dry matter contents were highly significant for all the parents thereby indicating the predominance of additive gene effects in the expression of these characters (Table 6). Kivuva et al. (2015), Balcha (2015), and Rukundo et al. (2017) reported that the positive and significant GCA effects in agronomic traits indicate the presence of additive gene action and parents with these genetic characters could be considered as good combiners in a hybridization program. In this study, clone Tio-Joe had positive and significant GCA effects for number of storage roots, harvest index and beta carotene content, while clone Ininda had positive GCA effect for fresh root yield and dry matter content only (Table 6). Both clones could be useful in breeding programs that aim to improve these traits. All the $F_{1}$ progenies had significant SCA effects for beta carotene and dry matter content (Table 7) again confirming that both additive and non additive gene effects play an important role in the determination of the expression of these traits.

\subsection{Heterosis Effects}

Heterosis was detected in most of the crosses for fresh root yield, beta carotene and dry matter content (Table 8). Most of the mid and better-parent heterosis were positive, showing that there was a possibility of selecting progenies that out performed than their parents for fresh root yield. Accordingly, $F_{1}$ progenies from, TJ $\times$ KK, TJ $\times$ LD and IND $\times$ LD, had higher fresh root yield than their parents. Progenies from the crosses, DLV $\times$ LD and $\mathrm{TJ} \times \mathrm{LD}$ had positive mid and better-parent heterosis for beta carotene content whereas, $\mathrm{F}_{1}$ progenies from the crosses, IND $\times$ LD and TJ $\times$ IND, had positive mid and better-parent heterosis for root dry matter content. This indicated the highest performance of those crosses compared to their best performing parental clones. According to Mwanga et al. (2002) $\mathrm{F}_{1}$ progenies that had positive mid and better-parent heterosis outperformed their best parents for agronomic and nutrient parameters whereas progenies with negative mid and better-parent heterosis were considered good for resistance to diseases.

\subsection{Heritability}

Beta carotene and dry matter content also gave high broad-sense heritability values than yield and yield components again indicating the predominance of gene action in beta carotene and dry matter content (Table 9). These results are also in conformity with those of Cervantes-Flore (2006), Courtney et al. (2008), and Baafi et al. (2016) but are validated with those of Cervantes-Flores (2006) that showed that high narrow sense heritability and additive gene action in root dry matter content may result in rapid improvement of this trait.

\subsection{Phenotypic Correlation between the Traits Studied}

In this study beta carotene content and root dry matter content were negatively correlated. This negative correlation may be associated with the fact that both, beta carotene and root dry matter contents are synthesized inside plastids, chromoplast and amyloplast, respectively. Therefore it is possible that chromoplast and amyloplast may be competing for the same organelles as reported by Cervantes-Flores et al. (2011). In addition, beta carotene content was negatively correlated with fresh root yield (Table 10) indicating that selection of genotypes for high beta carotene content would result in lower fresh root yield because of their negative association between them. The results were in accordance with those found by Tumwegamire et al. (2011). The estimations of beta carotene content through the color chart was significant and positively correlated with those from the laboratory analysis $(r=0.788)$ indicating that the color chart can be useful for sweet potato beta carotene content estimation.

\section{Conclusion}

In the sweet potato clones evaluated here, root yield and yield components were mostly influenced by environmental conditions, but beta carotene and dry matter content were under the expression of both the additive and non additive gene effects. The additive GCA effects in F1 progenies were reliably estimated by the Baker's ratio for all the traits. Clone Ininda had the highest GCA effects for fresh root yield and dry matter content, whereas clone, Tio-Joe had the highest GCA effects for beta carotene content. Clone, Lourdes was the best male parent for most of the traits studied. Crosses, IND $\times$ LD, KK $\times I N D, T J \times K K, T J \times I N D, K K \times D L V$ and DLV $\times$ LD had the highest SGA effects for fresh root yield whereas crosses derived from the clones Tio-Joe and Lourdes were the best performing for beta carotene content . For dry matter SGA effects were highest for $F_{1}$ progenies of, KK $\times \mathrm{DLV}, \mathrm{KK} \times \mathrm{LD}, \mathrm{IND} \times \mathrm{DLV}, \mathrm{IND} \times \mathrm{LD}$ and $\mathrm{DLV} \times \mathrm{LD}$. The positive mid and better-parent 
heterosis values indicated that for clonally propagated crops such as sweet potato, the $\mathrm{F}_{1}$ progenies can be selected, evaluated and released as a variety. Therefore sweet potato breeding might take the advantage of GCA effects generated during polycross mating and then proceed to exploit the SCA effects in $\mathrm{F}_{1}$ progeny selection.

\section{Acknowledgements}

This publication was made possible through support provided by the Alliance for a Green Revolution in Africa (AGRA) Grant No 2015 PASS 011. The opinions expressed herein are those of the author(s) and do not necessarily reflect the views of AGRA.

\section{References}

Baafi, E., Vernon, E. G., Joe, M.-A., Essie, T. B., Kwadwo, O., \& Edward, E. C. (2016). Genetic control of dry matter, starch and sugar content in sweetpotato. Acta Agriculturae Scandinavica. Section B: Soil and Plant Science. Munksgaard. https://doi.org/10.1080/09064710.2016.1225813

Baker, R. (1978). Issues in diallel analysis. Crop Science, 18, 533-536. https://doi.org/10.2135/cropsci1978. 0011183X001800040001x

Balcha, F. G. (2015). Breeding of sweetpotato for improvement of root dry matter and $\beta$-carotene contents in Ethiopia (PhD Thesis, University of KwaZulu-Natal, Republic of South Africa). Retrieved from http://hdl.handle.net/10413/14073

Burgos, G., Carpio, R., Sanchez, C., Sosa, P., Espinoza, J., \& Grüneberg, W. (2009). Guide for using the RHS color chart for selecting for high $\beta$-carotene swetpotato. ISTRC, Lima, Peru.

Burgos, G., Muñoa, L., Sosa, P., Cayhualla, E., Carpio, R., \& zum Felde, T. (2014). Procedures for chemical analysis of potato and sweetpotato samples at CIP's Quality and Nutrition Laboratory (p. 32). International Potato Center (CIP), Global Program Genetics and Crop Improvement, Lima, Peru. https://doi.org/ $10.4160 / 9789290604440$

Cervantes-Flores, J. C. (2006). Development of a Genetic Linkage Map and QTL Analysis in Sweetpotato (PhD thesis, North Carolina State University, Raleigh, USA). Retrieved from http://www.lib.ncsu.edu/resolver/ $1840.16 / 5679$

Cervantes-Flores, J. C., Sosinski, B., Pecota, K. V., Mwanga, R. O. M., Catignana, G. L., Truong, V. D., ... Yencho, G. C. (2011). Identification of quantitative trait loci for dry matter, starch, and $\beta$-carotene content in sweetpotato. Journal of Molecular Breeding, 28, 201-216. https://doi.org/10.1007/s11032-010-9474-5

Chiona, M. (2009). Towards enhancement of $\beta$-carotene content of high dry mass sweetpotato genotypes in Zambia (PhD thesis, University of Kwazulu-Natal, Pietermaritzburg, Republic of South Africa). Retrieved from https://books.google.co.ke/books?isbn=1780644205

Christie, B. R., \& Shattuck, V. I. (1992). The Diallel Cross: Design, Analysis, and Use for Plant Breeders. Plant Breeding Reviews, 9, 9-36. https://doi.org/10.1002/9780470650363.ch2

Chukwu, S. C., Okporie, E. O., Onyishi, G. C., Ekwu, L. G., Nwogbaga, A. C., \& Ede, N. V. (2016). Application of diallel analyses in crop improvement. Agric. Biol. J. N. Am., 7(2), 95-106. https://doi.org/10.5251/ abjna.2016.7.2.95.106

Courtney, M., Mcharo, M., La Bonte, D., \& Gruneberg, W. (2008). Heritability estimates for micronutrient composition of sweetpotato storage roots. Horticultural Science, 43, 1382-1384. Retrieved from http://hortsci.ashspublications.org/content/43/5/1382.full.pdf + html

Falconer, D. S., \& Mackay, T. F. C. (1996). Introduction to Quantitative Genetics (4th ed.) Longmans Green, Harlow, Essex, UK. Retrieved from http://www.genetics.org/content/167/4/1529.full.pdf

Fasahat, P., Rajabi, A., Rad, J. M., \& Derera, J. (2016). Principles and Utilization of Combining Ability in Plant Breeding. Biom Biostat Int J, 3(6), 00085. https://doi.org/10.15406/bbij.2016.04.00085

Griffing, B. (1956). Concept of General and Specific Combining Ability in Relation to Diallel Crossing Systems. Aust J Biol Sci, 9, 463-493. https://doi.org/10.1071/BI9560463

Harriman, J. C., \& Nwammadu, C. A. (2016). Utilisation of diallel analyses for heritability, GCA and SCA studies in crop improvement. American Advances Journal of Biological Sciences, 2(5), 159-167. https://doi.org/10.18869/AAJBS.2016.159

Harvest Plus. (2012). Disseminating Orange-Fleshed Sweet Potato: Mozambique Country Report. Washington, DC: Harvest Plus. Retrieved from http://OFSP_Country_Report_Mozambique_English_web.pdf 
Hayman, B. I. (1954). The Theory and Analysis of Diallel Crosses. Genetics, 39(6), 789-809.

Kivuva, B. M., Mwangi, S. G., Yencho, G. C., \& Sibiya, J. (2015). Combining ability and heterosis for yield and drought tolerance traits under managed drought stress in sweetpotato. Euphytica, 201, 423-440. https://doi.org/10.1007/s10681-014-1230-1

Low, J., Kinyae, P., Gichuki, S., Anyango, M., Hagenimana, V., \& Kabira, J. (1997). Combating Vitamin A Deficiency through the use of sweet potato (p. 110). Results from phase I of an action research project in South Nyanza, Kenya. International Potato Centre (CIP), Lima, Peru; Kenya Agriculture Research Institute (KARI), Kenya. Retrieved from http://agris.fao.org/agris-search/search.do?recordID=QP1998000049

Low, J., Lynam, J., Lemaga, B., Crissman, C., Barker, I., Thiele, G., ... Andrade, M. (2009). Sweetpotato in Sub-Saharan Africa. In G. Loebenstein \& G. Thottappilly (Eds.), The Sweetpotato (pp. 35-390). Springer. https://doi.org/10.1007/978-1-4020-9475-0_16

Low, J., Mwanga, R. O. M., Andrade, M., Carey, E., \& Ball, A. M. (2017). Tackling vitamin A deficiency with biofortified sweetpotato in sub-Saharan Africa. Global Food Security, 14, 23-30. https://doi.org/10.1016/ j.gfs.2017.01.004

Low, J., Walker, T., Hijmans, R. (2001). The potential impact of orange-fleshed sweet potatoes on vitamin A intake in Sub-Saharan Africa. Paper presented at a regional work shop on food based approaches to human nutritional deficiencies. The VITAA Project, Vitamin A and orange-fleshed sweet potatoes in Sub-Saharan Africa, 9-11 May, Nairobi, Kenya. Retrieved from http://www.cipotato.org/vitaa/Publications/Paper_ vitaa.pdf

Mwanga, R. O. M., Yencho, G. C., \& Moyer, J. W. (2002). Diallel analysis of sweet potatoes for resistance to sweet potato virus disease. Euphytica, 128, 237-248. https://doi.org/10.1023/A:1020828421757

Rukundo, P., Shimelis, H., Laing, M., \& Gahakwa, D. (2017). Combining Ability, Maternal Effects, and Heritability of Drought Tolerance, Yield and Yield Components in Sweetpotato. Front. Plant Sci., 7, 1981. https://doi.org/10.3389/fpls.2016.01981

Sharma, J. R. (2006). Statistical and Biometrical Techniques in Plant Breeding. New Age International, Daryaganj, New Delhi.

Stathers, T., Benjamin, M., Katcher, H., Blakenship, J., \& Low, J. (2013). Orange-fleshed sweetpotato and nutrition. Everything You Ever Wanted to Know about Sweetpotato: Reaching Agents of Change ToT Manual (Vol. 2). International Potato Center, Nairobi, Kenya. https://doi.org/10.4160/9789290604273.v2

Stathers, T., Mkumbira, J., Low, J., Tagwireyi, J., Munyua, H., Mbabu, A., \& Mulongo, G. (2015). Orange fleshed Sweetpotato Investment Guide (p. 39). International Potato Center, Nairobi, Kenya. https://doi.org/ $10.4160 / 9789290604600$

Tumwegamire, S., Regina, K., Patrick, R. R., Don, R. La B., Wolfgang, J. G., Gabriela, B., ... Robert, O. M. M. (2011). Evaluation of Dry Matter, Protein, Starch, Sucrose, b-carotene, Iron, Zinc, Calcium, and Magnesium in East African Sweetpotato (Ipomoea batatas (L.) Lam) Germplasm. Hortscience, 46(3), 348-357. Retrieved from http://hortsci.ashspublications.org/content/46/3/348.full

WHO (World Health Organization). (2009). Global prevalence of vitamin A deficiency in populations at risk 1995-2005. World Health Organization Global Database on Vitamin A Deficiency. World Health Organization, Geneva. Retrieved from http://www.who.int/vmnis/database/vitamina/x/en/

Woolfe, J. A. (1992). Sweetpotato: An Untapped Food Resource (p. 363). Cambridge University Press, Cambridge, UK. Retrieved from http://books.google.com/books?id=_MWmIDzNMSYC

\section{Copyrights}

Copyright for this article is retained by the author(s), with first publication rights granted to the journal.

This is an open-access article distributed under the terms and conditions of the Creative Commons Attribution license (http://creativecommons.org/licenses/by/4.0/). 